\title{
Assessment of Phenotypic Variability in Erwinia stewartii Based on Metabolic Profiles
}

\author{
W. J. Wilson and H. R. Dillard, Department of Plant Pathology, Cornell University, New York State Agricultural \\ Experiment Station, Geneva, NY 14456; and S. V. Beer, Department of Plant Pathology, Cornell University, Ithaca, \\ NY 14853
}

\begin{abstract}
Wilson, W. J., Dillard, H. R., and Beer, S. V. 1999. Assessment of phenotypic variability in Erwinia stewartii based on metabolic profiles. Plant Dis. 83:114-118.

One hundred twenty-four bacterial isolates originating from sweet corn or corn flea beetles in the northeastern, midwestern, and mid-Atlantic United States were verified as Erwinia stewartii (Pantoea stewartii subsp. stewartii) and characterized phenotypically by their respiratory response to 91 carbon sources. The unweighted pair group method of averages (UPGMA) was used to construct a dendrogram that revealed homogeneous metabolic profiles at $93 \%$ similarity. Two-thirds of the isolates formed 18 separate groups, each sharing the same metabolic profile. One-third of the isolates had distinct metabolic profiles. Most groups shared either isolation source, geographical location, and/or year of isolation. Members of some groups persisted through time and had been isolated from diverse geographical locations. Four representative strains of the proposed Pantoea stewartii subsp. indologenes were also characterized; their metabolic profiles were most similar to those of Erwinia herbicola (Pantoea agglomerans).
\end{abstract}

Stewart's bacterial wilt is a serious disease of corn (Zea mays L.) that sporadically causes significant losses to the sweet corn industry (15). The disease is caused by the bacterium Erwinia stewartii. Typical symptoms are rapid wilting of corn plants and leaves with water-soaked linear, pale green to yellow lesions and streaks. As the disease progresses, the streaks become dry and brown. Corn crops are at serious risk when infection occurs at the three- to five-leaf stage because this will result in severely stunted plants $(6,14)$.

The corn flea beetle, Chaetocnema pulicaria is considered the most important overwintering host and vector of $E$. stewartii (17). Corn flea beetle populations are directly proportional to Stewart's wilt incidence; therefore, the abundance of $E$. stewartii primary inoculum is related to corn flea beetle populations (21). Corn flea beetles are susceptible to freezing temperatures, and in harsh winters flea beetle mortality is high, which leads to low incidence of Stewart's wilt the following growing season (21). These relationships were coupled to develop an

Corresponding author: W. J. Wilson

E-mail: wilson69@1lnl.gov

Current address of W. J. Wilson: Biology and Biotechnology Research Program, Lawrence Livermore National Laboratory, L-452 P.O.Box 808, Livermore, CA 94551.

Accepted for publication 21 October 1998.

Publication no. D-1998-1130-04R

(c) 1999 The American Phytopathological Society often-used predictive system for disease severity $(4,5)$.

Incidences of Stewart's bacterial wilt were high in New York State during the four growing seasons from 1988 to 1991 , and strains of E. stewartii were isolated from diseased sweet corn and corn flea beetles at those times. To determine the similarity of strains isolated in New York, a large number was collected from infected plants in New York and from the northeastern, midwestern, and mid-Atlantic United States. Additional strains were acquired from culture collections to represent past Stewart's wilt outbreaks and their geographical locations.

Mergaert et al. (11) proposed that $E$. stewartii be moved to the genus Pantoea based on DNA-DNA hybridization studies. Similar experiments also indicated that several previously named $E$. herbicola and $E$. ananas strains be moved as subspecies indologenes of the proposed Pantoea stewartii and the pathogen be designated subspecies stewartii.

Biolog Inc. (Hayward, CA) has developed a technique to identify bacteria based on differential utilization of 95 carbon sources, each dried into a separate well of a 96-well microplate (3). Utilization of a particular carbon is visualized by a purple color change from the reduction of the redox dye tetrazolium violet. The results of 91 carbon sources in the Biolog GN gramnegative microplate have been used to compile a database of 124 E. stewartii strains.

Our objective was to use the metabolic profiles of these 124 strains to study phenotypic variability within this species. Four representative strains of the proposed Pantoea stewartii subsp. indologenes were included for comparison purposes.

\section{MATERIALS AND METHODS}

Bacterial strains. Strains of E. stewartii and other bacteria included in the study are listed in Table 1. Bacterial strains from 1991 to 1994 were isolated directly from sweet corn plants and corn flea beetles onto Miller-Schroth selective media (12). Older strains were retrieved from culture collection stocks, as indicated in Table 1. All strains were confirmed as E. stewartii by colony morphology, gram-reaction, oxidation-fermentation reaction $(\mathrm{O} / \mathrm{F})$, lack of motility, reaction to specific E. stewartii primers using a polymerase chain reactioncoupled ligase chain reaction assay (PCRcoupled LCR) $(24,25)$, and pathogenicity on the susceptible sweet corn cultivar Jubilee. Bacteria were stored at $-70^{\circ} \mathrm{C}$. For carbohydrate utilization testing, strains were taken from frozen stock, transferred twice on trypticase soy agar (TSA) (Becton Dickinson, Cockeysville, MD), and prepared for inoculation onto the Biolog GN microplates.

Carbohydrate utilization. Bacterial cells were incubated for $24 \mathrm{~h}$ on TSA and suspended in sterile saline at $A_{600}$ of between 0.285 and 0.330. A Biolog GN microplate was immediately inoculated with the suspension at $150 \mu \mathrm{l}$ per well and incubated at $28^{\circ} \mathrm{C}$ for $24 \mathrm{~h}$. Reactions in individual wells were scored visually as positive (purple color in well) or negative (no color) in reference to a negative control well containing no carbon source.

Results of 91 carbon tests were stored as a user database using the Biolog Microlog 3.5 software. The user database was analyzed with the Biolog MLCLUST program by an unweighted pair-group method analysis (UPGMA) to construct a dendrogram and by principal component analysis (PCA) for a three-dimensional picture.

Test error and reproducibility. Because of the possible variability of carbon source utilization due to sampling and growing of bacteria (18), we followed a standardized protocol similar to that suggested by Biolog Inc. (3). Test reproducibility was assessed by replicating $15 \%$ of the strains (1). Individual carbohydrate test variance $\left(S_{i}^{2}=n / 2 t\right)$ (1) was calculated from 18 replicated strains, where $n=$ number of replicated strains with a discrepant 
carbohydrate utilization result and $t=$ total number of replicated strains. The pooled variance, $S^{2}$, was calculated by averaging the individual test variances. The pooled variance was used to find the average probability of an erroneous test result $(P=$ $1 / 2\left[1-4\left(S^{2}\right)\right]$.

Numerical analyses. Carbohydrate utilization results were analyzed by UPGMA. This phenetic method uses a sequential clustering algorithm to identify each strain's metabolic profile in order of similarity (10). A dendrogram was constructed based on UPGMA information (Figs. 1 and 2).

A three-dimensional taxonomic map of the data was made using PCA (Fig. 3). PCA is an ordination method that simplifies taxonomic space to three dimensions so that relationships between bacterial strains can be displayed pictorially. The first dimension represents the greatest variability among the bacterial strains, and the next two dimensions account for the next two levels of greatest variability (10).

\section{RESULTS}

Test error and reproducibility. Metabolic profiles were obtained for $124 E$. stewartii strains. Since E. stewartii was not included in the Biolog Microlog $3.5 \mathrm{~N}$ database, E. amylovora, E. herbicola, and Pseudomonas syringae pv. phaseolicola strains were used as control organisms to verify the microplates were functioning properly. Microlog correctly identified the control organisms. Reproducibility of the test was assessed by replicating $15 \%$ of the strains (1). The pooled variance, $S^{2}$, was calculated by averaging the individual test variances for an overall error estimate of $5 \%$. The probability of an erroneous test result was $6 \%$ and resulted from high individual probability errors for four carbohydrate tests: Tween 40 (68\%), dextrin $(20 \%)$, inosine $(17 \%)$, and glycogen (17\%). Reproducible results are difficult to obtain with certain carbohydrate tests for some bacterial species. These tests, if included in analyses, could lead to experimental errors when compiling similarity values $(1,20)$. Austin and Priest (1) suggest rejecting tests where the individual probability errors are over 10 to $15 \%$. Thus, the four carbohydrate tests were deleted from the data set. The resulting average probability of an erroneous test result was $1.2 \%$.

Carbon source utilization of $E$. stewartii strains. Twenty-six percent of the carbon sources were utilized by all $E$. stewartii strains tested. They were: L-serine, $N$-acetyl-D-glucosamine, L-arabinose, D-fructose, D-galactose, $\alpha$-D-glucose, $M$ inositol, D-mannose, D-melibiose, D-psicose, D-raffinose, sucrose, D-trehalose, mono-methyl succinate, D-gluconic acid, succinic acid, bromo-succinic acid, Lalanine, L-alanyl glycine, L-asparagine, Lglutamic acid, glycyl-L-aspartic acid, gly-
cyl-L-glutamic acid, glycerol, glucose-6phosphate, and glucose-1-phosphate.

Carbon sources not utilized by any $E$. stewartii strain were: Tween $80, \mathrm{~N}$-acetylD-glucosamine, adonitol, D-arabitol, cellobiose, gentibiose, L-rhamnose, turanose, xylitol, D-galactonic acid lactone, D-galacturonic acid, D-glucosaminic acid, $\beta$ hydroxybutric acid, $\gamma$-hydroxybutyric acid, D,L- $\alpha$-glycerol phosphate, itaconic acid, $\alpha$ ketobutyric acid, $\alpha$-ketoglutaric acid, malonic acid, quinic acid, D-saccharic acid, sebacic acid, L-histidine, hydroxy-Lproline, L-leucine, L-ornithine, L-pyroglutamic acid, $\gamma$-aminobutyric acid, phenyl ethylamine, 2-aminoethanol, $p$-hydroxyphenylacetic acid, L-phenylalanine, D,Lcarnitine, urocanic acid, putrescine, 2,3butanediol, and L-threonine.

Variable carbon source utilization and percentage of E. stewartii strains utilizing those carbon sources are listed in Table 2.

Phenetic analysis. A dendrogram was constructed from the 131 bacterial strains tested (Figs. 1 and 2). One carbon test difference between strains is equivalent to one hatch mark $(1 \%)$ on the dendrogram. E. stewartii strains clustered together into one phenon at $93 \%$ similarity. One outlier, Es69, was present at $89 \%$ similarity to the other strains. E. amylovora, E. herbicola, and $P$. syringae pv. phaseolicola were 85 , 78 , and $72 \%$ similar, respectively. A taxonomic map of the data was made by threedimensional principal component analysis (PCA) (Fig. 3). PCA of the 131 bacterial strains also revealed the homogeneity within the E. stewartii species. Four strains of bacteria proposed as a new subspecies of E. stewartii clustered with the E. herbicola strain in both the dendrogram and PCA.

\section{DISCUSSION}

The Biolog system provided a robust, standardized method to gather a large set of individual carbohydrate utilization data (3). Both UPGMA and PCA of the carbon utilization data successfully differentiated two other Erwinia sp. and P. syringae pv.

Table 1. Bacterial strains and geographical origin

\begin{tabular}{|c|c|}
\hline $\operatorname{Strain}(\mathbf{s})^{\text {a }}$, source & Origin \\
\hline \multicolumn{2}{|l|}{ Erwinia stewartii } \\
\hline Es61-92 & Delaware, $1994, \mathrm{CFB}^{\mathrm{b}}$ \\
\hline Es93-95 & Delaware, 1994, corn \\
\hline Es4,8,9 & Genessee Co., NY, 1991, corn \\
\hline Es1,51-53 & Wayne Co., NY, 1991, corn \\
\hline Es5,32,33,35,49,50,54 & Ontario Co., NY, 1991, corn \\
\hline Es12-14 & Onondaga Co., NY, 1991, corn \\
\hline Es $2,3,10,11$ & Cayuga Co., NY, 1991, corn \\
\hline Es29-31,34,36 & Yates Co., NY, 1991, corn \\
\hline Es37,38 & Seneca Co., NY, 1991, corn \\
\hline Es7 & Saratoga Co., NY, 1991, corn \\
\hline Es17-21 & Schenactady Co., NY, 1991, corn \\
\hline Es26-28 & Rensselaer Co., NY, 1991, corn \\
\hline Es16,22-25 & Columbia Co., NY, 1991, corn \\
\hline Es15,56-60 & Ulster Co., NY 1991, corn \\
\hline Es39-48 & Suffolk Co., NY, 1991, corn \\
\hline Es100-106 (CUCPB 0176-0182) & New York, 1975, corn \\
\hline Es6 & Illinois, 1984, corn \\
\hline Es109-114 & Illinois, 1993, corn \\
\hline Es55 & Maryland, 1991, corn \\
\hline Es95 (CUCPB 2993) & Ohio, 1974 , corn \\
\hline Es96 (CUCPB 2994) & Indiana, 1975 , corn \\
\hline Es97 (CUCPB 2995) & Kentucky, 1975, corn \\
\hline Es98 (CUCPB 2996) & Tennessee, 1975, corn \\
\hline Es99 (CUCPB 2997) & Missouri, 1975, corn \\
\hline Es115 (NCPPB 449) & USA, 1957, corn \\
\hline Es116 (Z05) & USA, corn \\
\hline Es117 (CUCPB 1374) & USA, 1932, corn \\
\hline Es118 (CUCPB 1375) & New York, 1965, corn \\
\hline Es119,120 (DC116,DC122) & Missouri, 1976, corn \\
\hline Es121-123 (ATCC 29227-29229) & Connecticut, 1975, CFB \\
\hline Es124 & Illinois, corn \\
\hline \multicolumn{2}{|l|}{ Pantoea stewartii subsp. indologenes } \\
\hline NCPPB 1845 & Pineapple, Hawaii, 1948 \\
\hline NCPPB 1562 & Pearl millet, India, 1961 \\
\hline NCPPB 2275 & Pearl millet, India, 1966 \\
\hline NCPPB 2280 & Foxtail millet, India, 1960 \\
\hline Erwinia amylovora (CUCPB Ea321) & France, Hawthorne \\
\hline E. herbicola 1 & New York, 1993, corn \\
\hline Pseudomonas syringae pv. phaseolicola & New York, bean \\
\hline
\end{tabular}

${ }^{a}$ Strain names and numbers correspond to those in unweighted pair-group method analysis (UPGMA). Other designation, if any, is in parentheses: CUCPB, Cornell University Collection of Phytopathogenic Bacteria; NCPPB, National Collection of Plant Pathogenic Bacteria; ATCC, American Type Culture Collection; DC, supplied by Dave Coplin, Ohio State University.

${ }^{\mathrm{b}}$ Corn flea beetle. 
phaseolicola as distinct taxonomic units from E. stewartii. E. amylovora was $85 \%$ similar and E. herbicola was $78 \%$ similar to E. stewartii (Fig. 1). These results were consistent with those of a previous study by Verdonck et al. (22) that analyzed numerically the genus Erwinia with 72 phenotypic tests using API 20E and API 50CHE (API Systems, bioMerieux Vitek, Inc., Hazelwood, MO). The four $E$. stewartii strains tested in that study clustered at $96 \%$ similarity; our extensive collection of E. stewartii strains confirmed the homogeneous nature of E. stewartii. Generally, phenetic groups formed at about $80 \%$ similarity are equivalent to a bacterial species (19).

There was some variation in the ability of E. stewartii strains to utilize carbon sources. This variation separated 83 strains into 18 groups of two or more isolates with the same metabolic profile (phenotype) (Figs. 1 and 2, Table 1). Ten phenotypes consisted solely of isolates from a certain year, source (corn flea beetle or sweet corn), and/or location (e.g., corn flea beetles, Delaware, 1994), but there were also phenotypes containing isolates from diverse sources.

One phenotype consisted of 18 isolates (beginning at Es28 on the dendrogram pictured in Fig. 1), 12 of which were collected from New York State during a 1991 outbreak of Stewart's bacterial wilt. Other members of this phenotype were collected from Tennessee (Es98), Ohio (Es108), Illinois (Es124), and Connecticut (Es122) from 1974-75 and from Delaware (Es68) in 1994. The isolates from Connecticut and Delaware came from corn flea beetles. Another phenotype (beginning with Es16, Fig. 2) contained nine isolates from the NYS 1991 outbreak and one Ohio isolate collected in 1967. It has been shown that other bacterial species may persist for long periods of time and achieve widespread geographic distributions (23). This seems to be true of several E. stewartii phenotypes, assuming their metabolic profiles reflect their genotype.

A corn flea beetle isolate (Es75) and a sweet corn isolate (Es93), from adjacent fields in Delaware, shared identical metabolic profiles, suggesting a single pathogenic phenotype's association in vector and host. Evidence for the geographical stability of a phenotype is shown in Figure 2 by the identical metabolic profiles of an Illinois phenotype isolated from corn in 1984 (Es6) and in 1993 (Es111).

E. stewartii was isolated from two separate lesions on each of 11 single corn plants collected from different counties in the 1991 NYS outbreak. One plant contained two isolates representing the same phenotype (Es29 and Es30) (Fig. 2); the other plants contained isolates with different metabolic profiles. In 1991, there were high populations of corn flea beetles, and it was common to see more than one beetle on a single corn plant. A plant infested by more than one beetle could contain several different phenotypes. Corn flea beetles may also have had more than one phenotype in their intestinal tract.

In a study by Mergaert et al. (11), results from DNA-DNA hybridization experiments suggested that E. stewartii was more similar to E. herbicola (Pantoea agglomerans) than to E. amylovora, and proposed that $E$. stewartii be transferred to the genus Pantoea. Furthermore, based on similar DNA-DNA hybridization experiments, 10 strains formally identified as E. herbicola and E. ananas were found to be borderline for inclusion in the new species $P$. stewartii (Smith) Mergaert. However, electrophoretic protein profiles and other phenotypic tests discriminated between the 10 strains and $P$. stewartii; the strains were transferred to the new subspecies $P$. stewartii subsp. indologenes.

Four representative strains (NCPPB $1845,1562,2275$, and 2280), one from each protein profile group of this proposed subspecies, were included in our carbohydrate utilization studies. All four strains clustered with the E. herbicola strain and

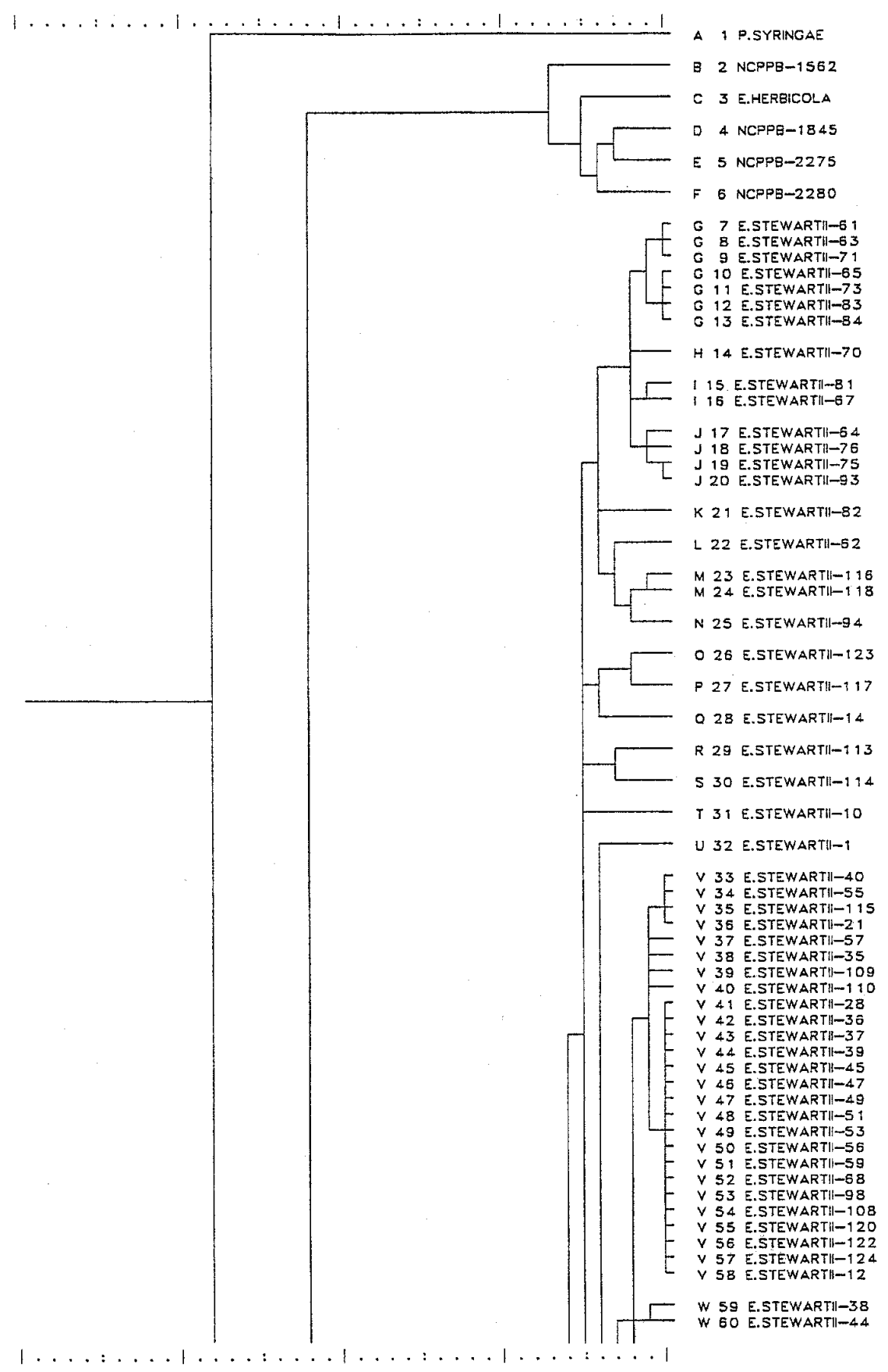

Fig. 1. First half of the dendrogram of Erwinia stewartii strains assembled by unweighted pair-group method analysis (UPGMA). Each hatch mark on the dendrogram is equivalent to one carbon test difference between strains. Refer to Table 1 for the key to the Erwinia strains (Es1 = E. stewartii-1). 
were only $78 \%$ similar to $E$. stewartii. They were not pathogenic on sweet corn cultivar Jubilee. Three of the strains showed typical E. herbicola reactions for $\mathrm{O} / \mathrm{F}$ and motility. They were also LCR(-) when tested using a PCR-coupled LCR assay specific for E. stewartii (24).

One strain in our study, NCPPB 1845 , showed characteristics of both E. stewar- tii and E. herbicola. It was $\mathrm{O} / \mathrm{F}(+)$ and nonmotile like E. stewartii, but it had a carbohydrate utilization profile similar to E. herbicola. It was also identified as LCR $(+)$ by the PCR-coupled LCR assay specific for E. stewartii (24). This strain was isolated from pineapple in Hawaii and was classified originally as $E$. ananas. It seems that this strain may be

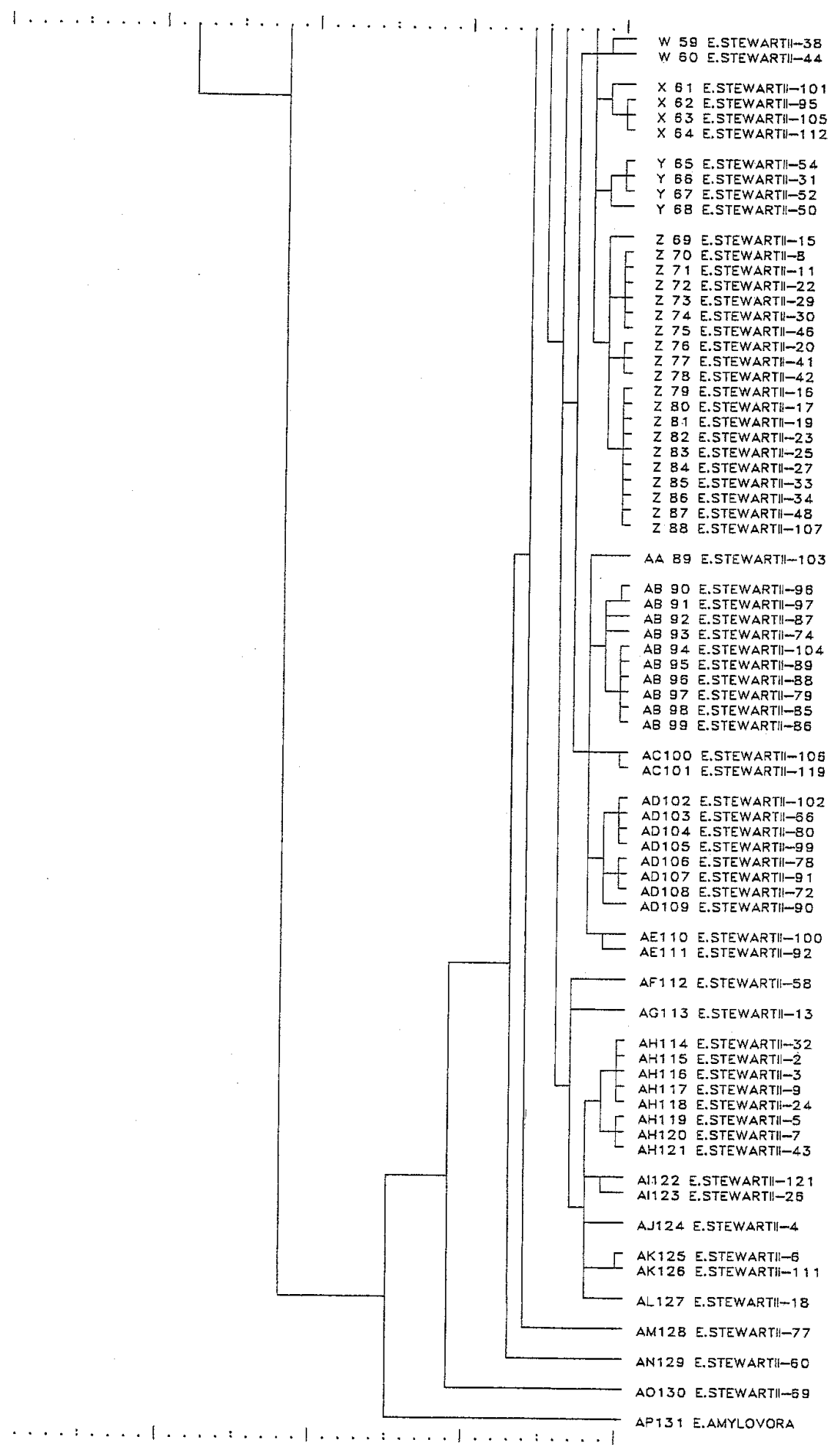

Fig. 2. Second half of dendrogram of Erwinia stewartii strains assembled by unweighted pair-group method analysis (UPGMA). Refer to Table 1 for the key to the Erwinia strains. an intermediate between E. herbicola and E. stewartii.

From UPGMA and PCA, none of the proposed $P$. stewartii subsp. indologenes strains appeared similar to E. stewartii. Furthermore, the subspecies indologenes strains were found on different hosts in geographically isolated regions, from grasses in India and pineapple in Hawaii. E. stewartii has never been reported from these regions, where its main plant host, corn, is not native. Since these strains were borderline for inclusion in E. stewartii by DNA-DNA hybridization analysis and have obvious differences in electrophoretic protein and carbohydrate utilization profiles, it may be more relevant biologically to treat them as separate species. The definitive test of this taxonomic and ultimately phylogenetic question would be a study of the $16 \mathrm{~S}$ rDNA of the Erwinia group (26).

In our study, E. stewartii was phenotypically most similar to E. amylovora. The two plant pathogens share significant homologies in the hypersensitive response and pathogenicity ( $h r p$ ) and water-soaking (wts) gene clusters, respectively (9). Perhaps the carbohydrate utilization data reflect the parasitic lifestyle of these bacteria (11).

Numerical taxonomy of phenotypic characters is one measure of the variability of an organism. It is possible that the lack of phenotypic diversity in our E. stewartii isolates is because most samples were collected in eastern North America, where sweet corn is widely grown. However, the

Table 2. Variable carbon compound utilization and percentage of Erwinia stewartii strains using the carbon source, as determined by the standard BIOLOG GN microplate test

\begin{tabular}{lc}
\hline Compound & \% strains \\
\hline Aspartic acid & 99 \\
$\beta$-Methyl-D-glucoside & 99 \\
L-Proline & 98 \\
Methyl pyruvate & 97 \\
Thymidine & 95 \\
D-Mannitol & 93 \\
Lactic acid & 87 \\
D-Alanine & 81 \\
Acetic acid & 50 \\
Succinamic acid & 40 \\
Sorbitol & 27 \\
Lactulose & 24 \\
Maltose & 17 \\
$\alpha$-D-Serine & 15 \\
Uridine & 6 \\
L-Fucose & 5 \\
Propionic acid & 3 \\
$\alpha$-Cyclodextrin & 2 \\
Glucuronamide & 2 \\
Citric acid & 1 \\
Alaninamide & 1 \\
I-Erythritol & 1 \\
cis-Aconitic acid & 1 \\
Hydroxybutyric acid & 1 \\
L-Threonine & 1 \\
$\alpha$-Keto valeric acid & 1 \\
$\alpha$-D-Lactose & 1 \\
\hline
\end{tabular}




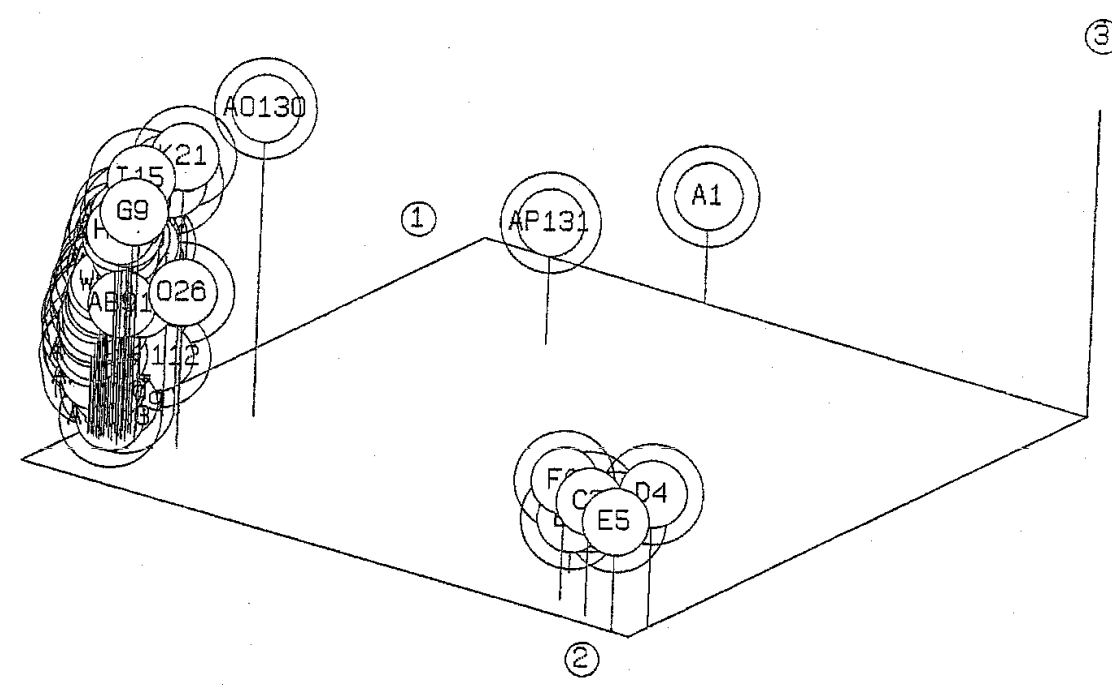

Fig. 3. Principal component analysis (PCA) of Erwinia stewartii strains. Number-letter combinations refer to groups and strains in the dendrogram. $\mathrm{A} 1=$ Pseudomonas syringae $; \mathrm{E} 5=$ member of E. herbicola cluster; $\mathrm{AP} 131=$ E. amylovora $; \mathrm{G} 9=$ member of $E$. stewartii cluster. Circled numbers 1,2 , and 3 represent the three dimensions of PCA.

phenotypic homogeneity may imply that the pathogen has been streamlined to exist in particular hosts; one might expect greater diversity in an organism surviving more ubiquitously in the environment (16).

An appreciation of the phenotypic diversity of $E$. stewartii may be useful in understanding the epidemiology of Stewart's bacterial wilt and the biology of the pathogen. Poos (17) showed that E. stewartii overwinters only in adult corn flea beetles and in no other insect vectors. In another study, no E. stewartii was isolated from weed sources in New York State or Delaware (24), and therefore weed reservoirs could not be confirmed for Stewart's wilt. Recent research reports indicate there is negligible evidence of seed transmission of E. stewartii in plants with less than $50 \%$ diseased leaf area $(2,8)$. From these findings, we hypothesize that E. stewartii is a specialist surviving in two main habitats, corn flea beetles and Z. mays. In occupying these particular niches, the relatively predictable environments may have selected for the homogeneous metabolic profile seen in this pathogen (13). In contrast, nonspecialist erwinias like E. herbicola and $E$. carotovora are ubiquitous in nature (16). Studies by Dye (7) revealed these to be phenotypically diverse species.

\section{ACKNOWLEDGMENTS}

This work was supported by a grant from the

\section{LITERATURE CITED}

1. Austin, B., and Priest, F. 1986. Modern Bacterial Taxonomy. Van Nostrand Reinhold, Workingham, Berkshire, UK.

2. Block, C. C., Hill, J. H., and McGee, D. C. 1998. Seed transmission of Pantoea stewartii in field and sweet corn. Plant Dis. 82:775780 .

3. Bochner, B. R. 1989. Sleuthing out bacterial identities. Nature 339:157-158.

4. Boewe, G. H. 1959. Stewart's disease prospects for 1950. Plant Dis. Rep. 34:155.

5. Castor, L. L., Ayers, J. E., MacNab, A. A., and Krause, R. A. 1975. Computerized forecast system for Stewart's bacterial disease on corn.

6. Dillard, H. R., and Kline, W. L. 1989. An outbreak of Stewart's bacterial wilt of corn in New York State. Plant Dis. 73:273.

7. Dye, D. W. 1981. A numerical taxonomic study of the genus Erwinia. N.Z. J. Agric. Res. 24:223-229.

8. Khan, A., Ries, S. M., and Pataky, J. K. 1996. Transmission of Erwinia stewartii through seed of resistant and susceptible field and sweet corn. Plant Dis. 80:398-403.

9. Laby, R. J., and Beer, S. V. 1992. Hybridization and functional complementation of the hrp gene cluster from Erwinia amylovora strain Ea321 with DNA of other bacteria. Mol. Plant-Microbe Interact. 412-419.

10. Li, W. H., and Graur, D. 1991. Fundamentals New York State Sweet Corn Research Association. Plant Dis. Rep. 59:533-536. of Molecular Evolution. Sinauer Associates, Inc., Sunderland, MA.

11. Mergaert, J., Verdonck, L., and Kersters, K. 1993. Transfer of Erwinia ananas (synonym, Erwinia uredovora) and Erwinia stewartii to genus Pantoea emend. as Pantoea ananas (Serrano 1928) comb. nov. and Pantoea stewartii (Smith 1898) comb. nov., respectively, and description of Pantoea stewartii subsp. indologenes subsp. nov. Int. J. Syst. Bacteriol. 43:162-173.

12. Miller, T. D., and Schroth, M. N. 1972 Monitoring the epiphytic population of $\mathrm{Er}$ winia amylovora on pear with a selective medium. Phytopathology 62:1175-1182.

13. Nevo, E., and Cleve, H. 1978. Genetic differentiation during speciation. Nature 275:125

14. Pataky, J. K., and Eastburn, D. M. 1993. Using hybrid disease nurseries and yield loss studies to evaluate levels of resistance in sweet corn. Plant Dis. 77:760-765.

15. Pepper, E. H. 1967. Stewart's bacterial wilt of corn. Monograph no. 4. American Phytopathological Society, St. Paul, MN.

16. Perombelon, M. C. M. 1992. The genus Erwinia. Pages 2899-2921 in: The Prokaryotes. Vol. III. 2nd ed. A. Balows, H. G. Truper, M. Dworkin, W. Harder, and K. H. Schleifer, eds. Springer-Verlag, New York.

17. Poos, F. W. 1955. Studies of certain species of Chaetocnema. J. Econ. Entomol. 48:555-563.

18. Scortichini, M., and Rossi, M. P. 1995. Influence of subculturing some phytopathogenic bacteria on their carbohydrate utilization profile. Lett. Appl. Microbiol. 21:237-241.

19. Sneath, P. H. A. 1984. Numerical taxonomy. Pages 5-7 in: Bergey's Manual of Systematic Bacteriology. Vol. 1. N. R. Krieg and J. G. Holt, eds. Williams and Wilkins, Baltimore, MD.

20. Sneath, P. H. A., and Johnson, R. 1972. The influence on numerical taxonomic similarities of errors in microbiological tests. J. Gen. Microbiol. 72:372-391.

21. Stevens, N. E. 1934. Stewart's disease in relation to winter temperatures. Plant Dis. Rep. 18:141-149.

22. Verdonck, L., Mergaert, J., Rijckaert, C., Swings, J., Kersters, K., and De Ley, J. 1987. Genus Erwinia: Numerical analysis of phenotypic features. Int. J. Syst. Bacteriol. 37:418.

23. Whittam, T. S. 1989. Clonal dynamics of Escherichia coli in its natural habitat. Antonie van Leeuwenhoek 55:23-32.

24. Wilson, W. J. 1995. Detection and characterization of Erwinia stewartii, the cause of Stewart's bacterial wilt of maize. Ph.D. thesis. Cornell University, Ithaca, NY.

25. Wilson, W. J., Wiedmann, M., Dillard, H. R., and Batt, C. A. 1994. Identification of $\mathrm{Er}$ winia stewartii by a ligase chain reaction assay. Appl. Environ. Microbiol. 60:278-284.

26. Woese, C. R. 1987. Bacterial evolution. Microbiol. Rev. 51:221-271. 